Bock, Flenzel の實驗的脾性行血に關する知兄補遺

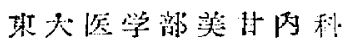

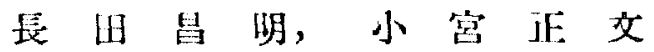

\title{
STUDIES ON THE EXPERIMENTAL ANEMIA PRODUCED BY THE \\ LIGATION OF THE SPLENIC VEIN IN DOGS.
}

By

Masaaki Nagata and Masafumi Komiya

Department of Internal Medicin, Tokyo University Medical School.

(Director: Prof. Y. Mikamo)

In 1938, Bock and Frenzel succeeded in produceing pancytopenia by the ligation of ihe splenic vein in rabbits. The results of the experiment was interpreted as supporting evidence of the existence of splenic hormones with an inbibitory influence on hematopoiesis. It was believed that the ligation of the splenic vein, blocking the splenic blood from the liver, resulted in the splenic hormones reaching the bone marrow in a higher concentration than normal, and that liver was capable of attenuating or otherwise an aff ?cting these hormones.

Jombres and Nielsen carried out the similar experiment with simultaneous bone marrow studies and Jombres came to the view that the pancytopenia occured as a result of an inhibited emission of the cells from the marrow with an accumlation of immature cell types, and Nielsen supposed the changes in the peripheral blood due to an incresed destruction of blood cells in the congested spleen because of no changes in the bone marrow.

In the following we should give a brief accounts of the results of some experiments in dogs, in which we have repeated Bock and Frenzel's procedure with or without splenectomy following the ligation of the splenic vein.

1) The ligation of the splenic vein blocking venøus return of the spleen to the liver resulted in normochromic and normocytic anemia with slight reticulocy topenia and initially moderate depressed erythropoiesis in bone marrow.

2) The congestion of the spleen improved quickly after the ligation of the splenic vein and the collateral communications of splenic vein to portal vessel were accomplished as early in the 2nd postoperative week.

3) The splenectomy after $4,7,14$, and 28 postoperative days did not give remarkable influences on the course of the anemia.

It is suggest that the anemia produced by the ligation of the splenic vein is due to the initial and temporal depression of the erythropoiesis and that the rôle of the spleen on this anemia must not be evaluated so excessively and the data obtained give not definite information on the pathogenesis of the anemia. 


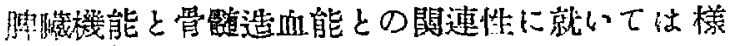
々、檍测か;行统れているか，今日のところ本課题 D解決法份望み難い段階にある。この閥にあっ

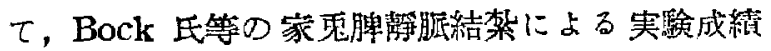

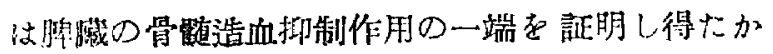
に忍われるが, Jombres, Nielsen 氏等の林梢珦. 液及び骨蹃像の詳細な迫試に上れば，同種実験に

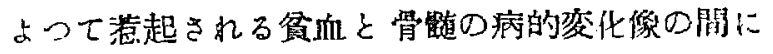

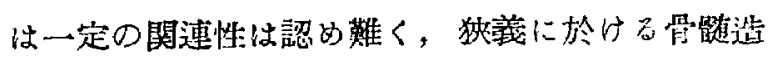
血.坜制に原因したものとは理解し難い战績走得て 浣る。

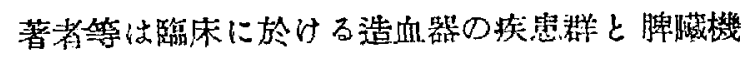
能の関連性老追究するにあたつて，Bock 氏等の 实験江與味を持古本資血の病態の把握と摘脾の影

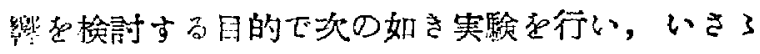

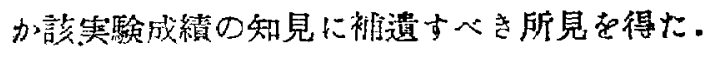

\section{實験方法}

实験動物浩健常成犬を使用した。

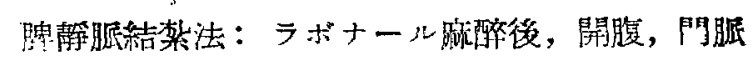

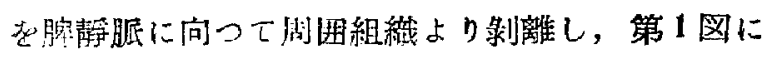
於付る A, B, Cの3 血管流会部老露恬し, 之等の

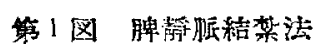

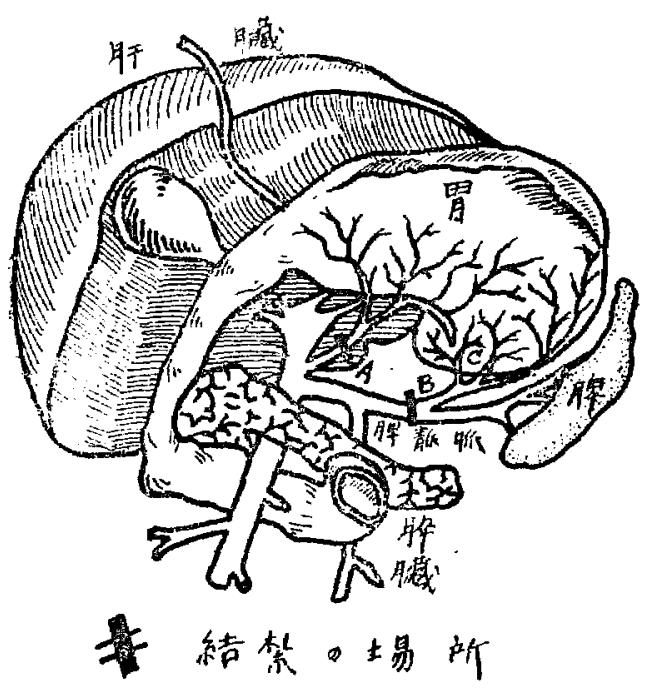

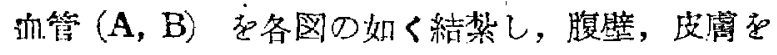

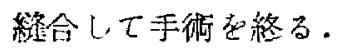

排䁬：上と同様に開腹後，型の如く脾藏を周国

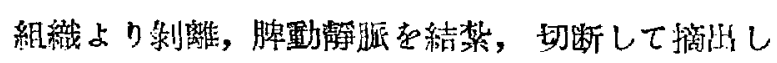
た.

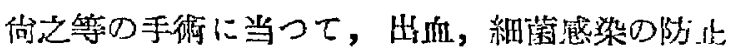
に特に留意し，挠者に対しては主としてべニシり ン投与を行なった。

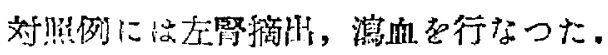

向液㭘查は型の如く, 浾的球数, 血色素量, 白

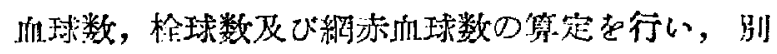

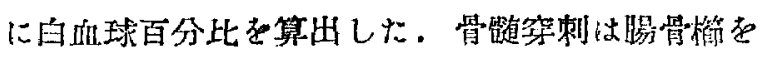
第刺し，有核細胞数の算定及ひ骨铕像 老検討し た。份骨榷像の検索に当つては，Reckers 氏等の 諭文を参照した。

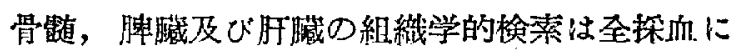
供つて死亡せしめた材料をホルマリン固定，へー トキシリン・エオシン染色で観察した。

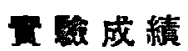

\section{(I) 脾静服結禁例の血液所見}

\section{(A) 末梢血液像}

3 例に就いて，凡飞10週間にわたり観察した成 績注下の如くである。

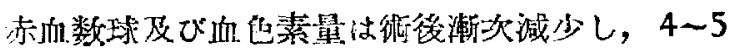
週後その最低值，即占術前の值に比して 40〜 50\%

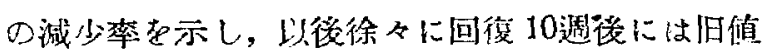
に近似した偭を示した，血他菜量は赤血球数と略 丩行して娍少し，徒つて任素指数の著明な変躇は 認好得なかった。䅅過中の赤血球形態の変化は顯

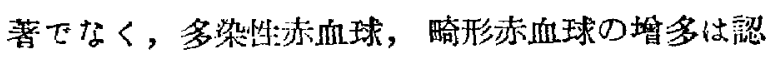

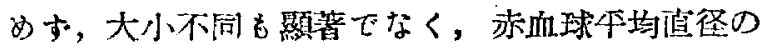

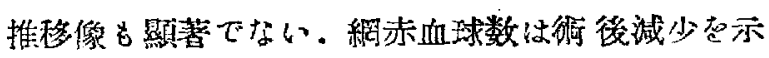
し貧血の回復期に稍增加士るが $20 \%$ を越えて增多 した例は証明されなかつた．血清胆色素濃鹿は全 経過中著変を示していない（第2，3図）

白血球数の変動は赤血球数の娍少々類似の態度 を示すもの，或は增娍不規則な释過走示す气の等 あつて，一定の傾向在把握し難く，百分比の上で

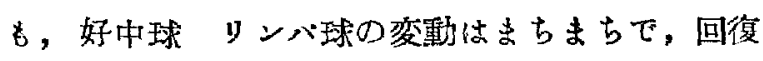

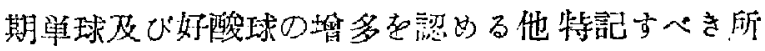
見军得なかつた。(第4图)

栓球数す白血球数の重播と類似して 実験例に上 
第 2 区 脾静胙結禁例の浾血球の变化

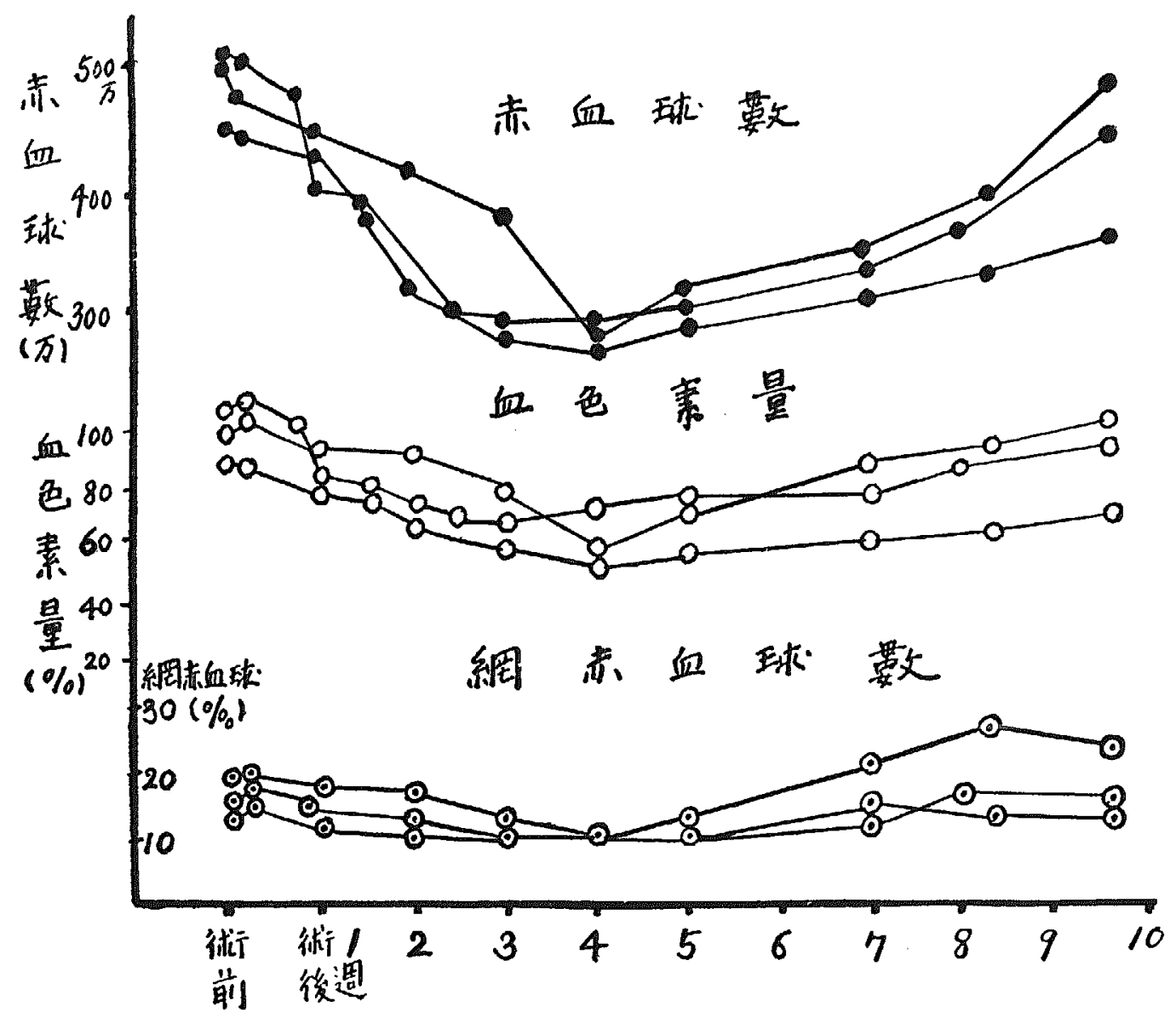

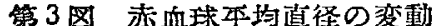

\begin{tabular}{|c|c|c|c|}
\hline & 術 前 & 舅 血 & 回復期 \\
\hline 結梀單独例 & $7.9 \mu$ & $8.0 \mu$ & $8.0 \mu$ \\
\hline $\begin{array}{c}\text { 結焚後腄摘例 } \\
\text { 宜 後 }\end{array}$ & 7.6 & 7.8 & 7.7 \\
\hline 4 日後 & 8.0 & 7.9 & 7.9 \\
\hline 7 日後 & 7.6 & 7.6 & 7.5 \\
\hline 14 日後 & 8.1 & 8.0 & 8.2 \\
\hline 28 日後 & 7.9 & 8.1 & 8.1 \\
\hline
\end{tabular}

つて相違した態度を亦し，第 $2 \sim 4$ 速に軽度の娍

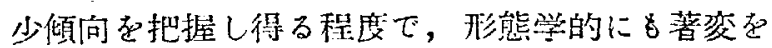
認め得ない(第 5 図).

(B) 骨跹穿刺液所見
短期間及び長期間観祭した 10例延べ23回の骨䨤 穿刺液所見を概略すると第 6 図の如き成綪を得 t.

有核細胞数は術後 1〜2週にかなり蕃しい減少 を示し，以後增加し旧值に復する徴を示した。

骨韨系細胞の百分比は術挠より2週間にわたり

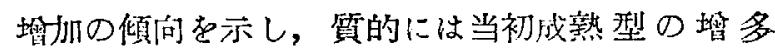

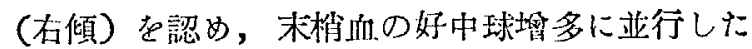

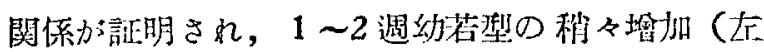
倾）した時期を経て，3週後は旧值に接近した。 特に成熟障害を思わせる病的形態は害証し難い。

赤势球系細胞は術後 1 週間かなり著明な減少を 示し，赤芽球の大多数は多色性及び正色性の正赤

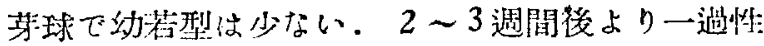

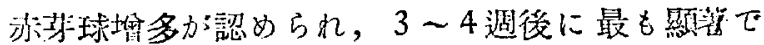




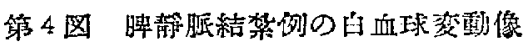

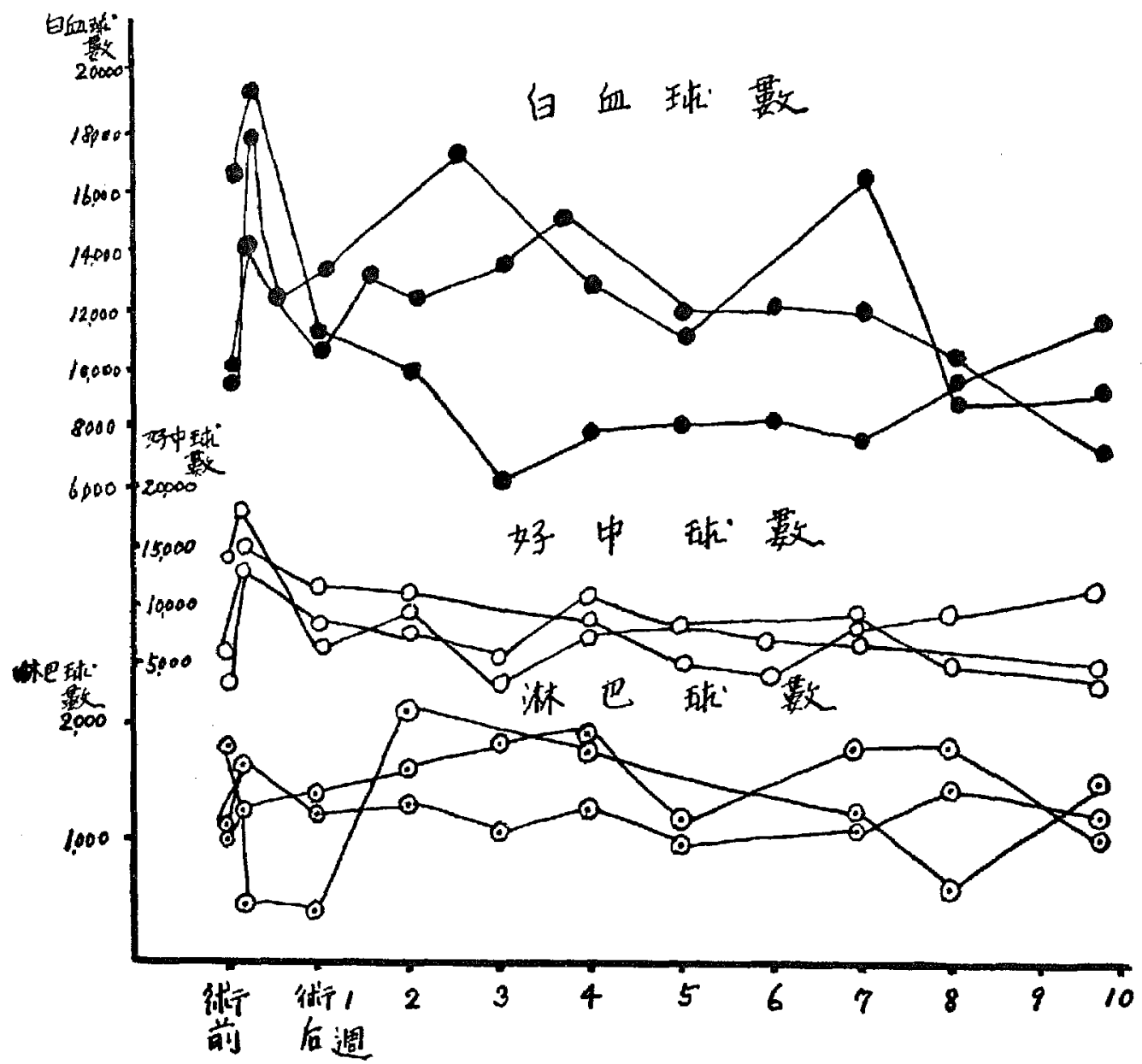

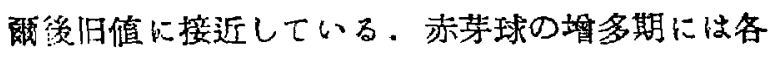
発育階榭の赤芽球が堌多しているが，就中多色性 欢び正色性正赤芽球の百分比が高い漛である，徒

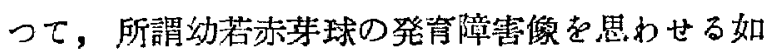
き形態変化は实証されていない。

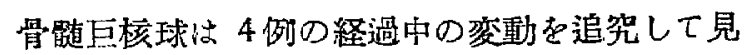

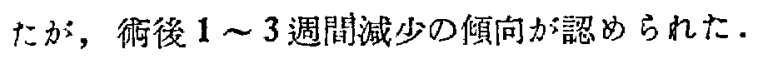

(是核球数は標本全視野の数から $1 \mathrm{cmm}$ 中の数 灻概算したものである）質的には娍少期の巨棱球

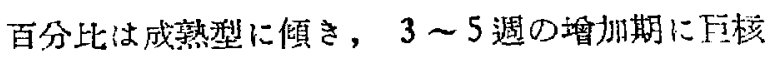
㳔球，前巨核球の百分比增多か認力られた。

単球は $2 \sim 5$ 週末梢血液內の一週性增多期に略

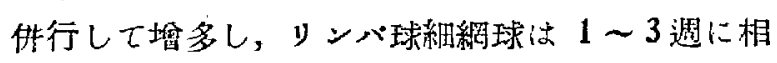

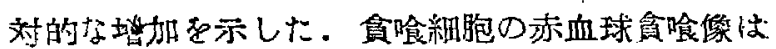
認められない，倘対照例には以上の如き変化に認 められなかつた（表略）。

(C) 手術徭脾より門脈への血管副行路形成の. 状況

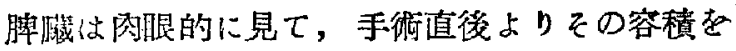
望し，著明な腫振を亦すが，10日頃よりその容積 は維小し，旧の大いさに復㷌する様である。脾動 墌にエバンス青を注入して，色素つ流れる方向を 観察すると，手淮直後にはメバンス靑は脾藏及び

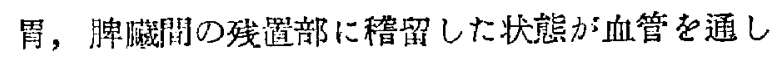
て青く見られるが手河面後の経過と共にがる像 は次第に不鮮明になつてくる状態がうかがれる。 

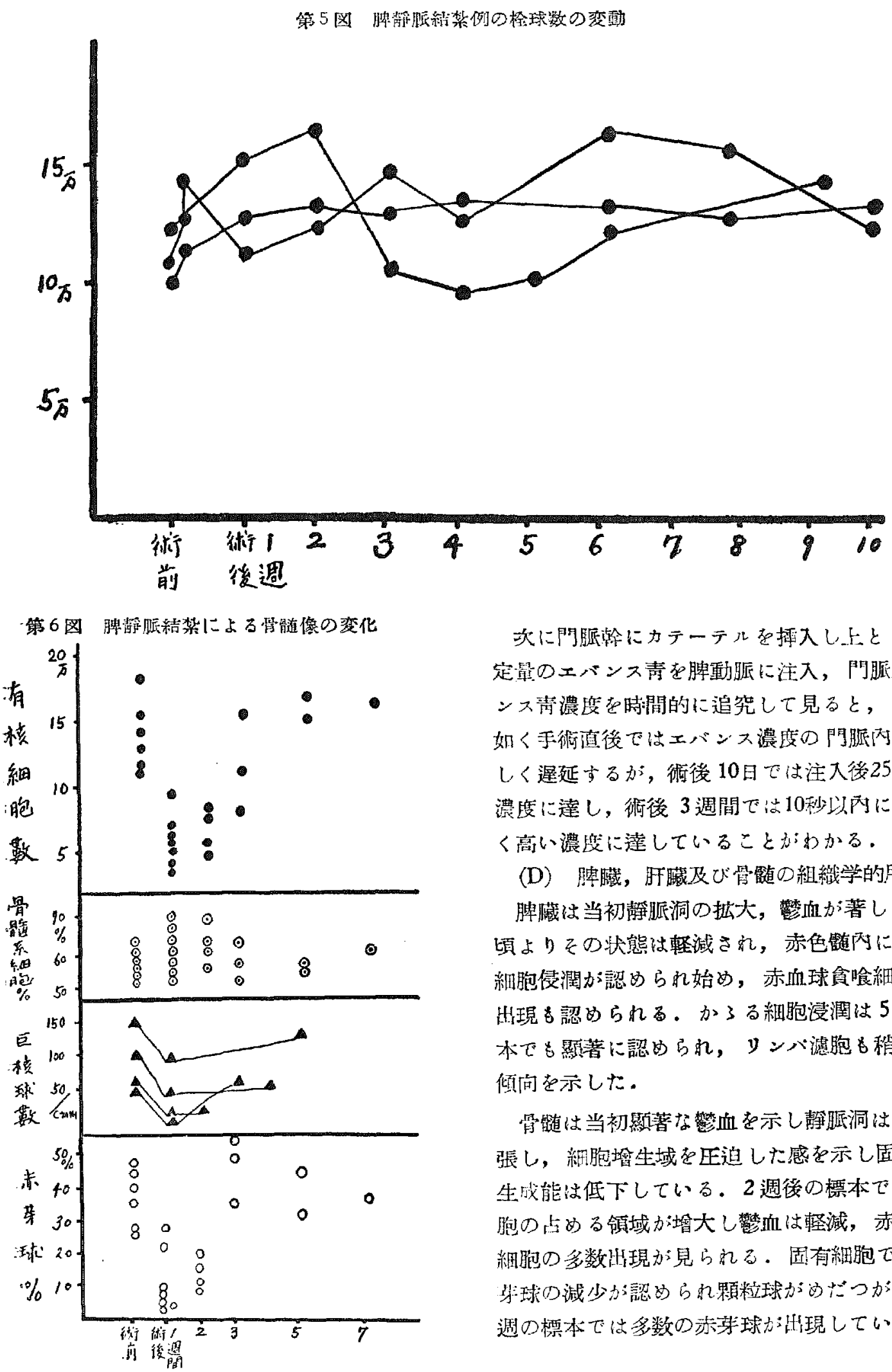

次に門胍幹にカテーテルを雨入したと间様に一

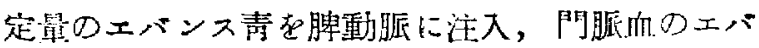
ンス青濃度支时間的に追究して見ると，第 7 図の

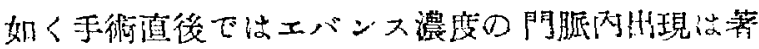

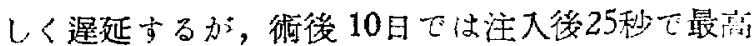

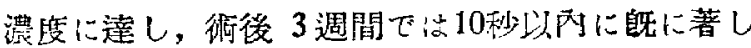
く离い濃㹂に澾していることわわかる。

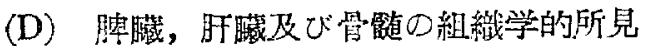

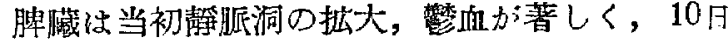
頃よりをの状態は軽減され，赤色龇入に円形核わ 細胞侵潤加認的ら始め，赤血球貪喰細胞の名数 出現す認曰られる。か了る細跑浸潤は 5 䓢後の標

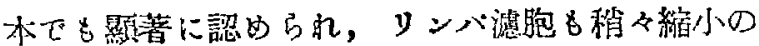
倾向を示した。

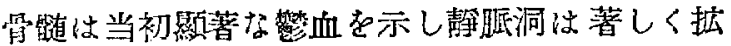

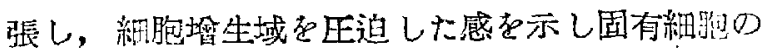
生成能は低下している。2週後の標本では固有細

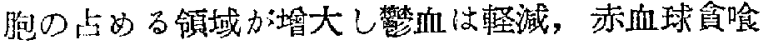

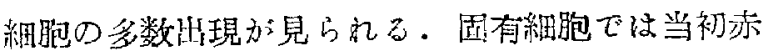

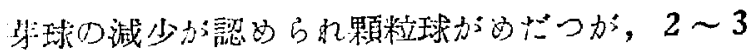
週の栖本では多数の亦芽球か出現している。厔核 


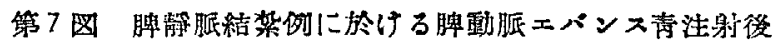

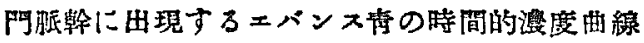

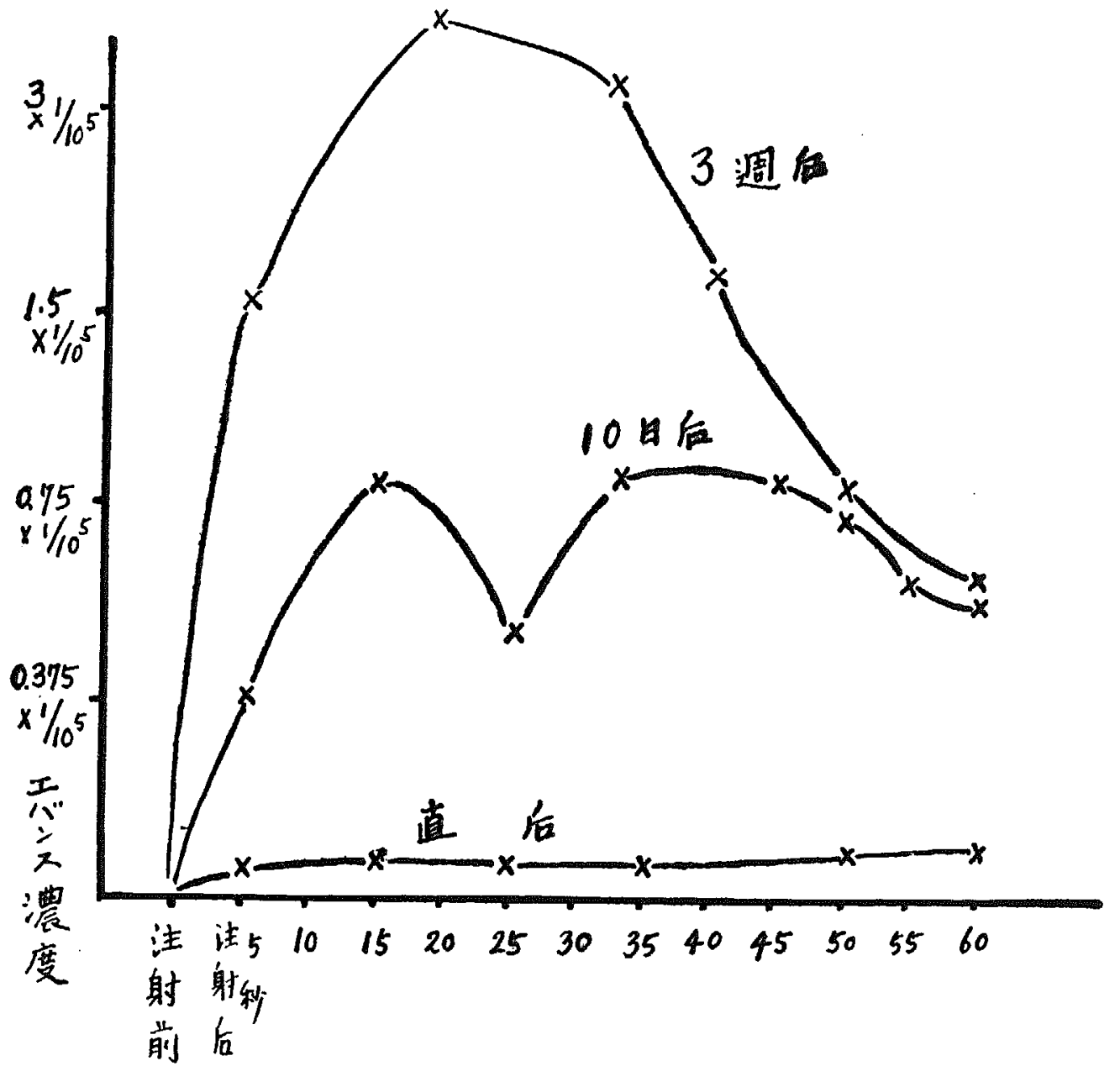

球は組織学的所見の上では $1 \sim 5$ 週の全経過にわ たり数量的にも，亦質的にも著しい変化像を証明 し得なかつた。肝臟には特記すべき所見を認めて いないので省略する。

（II）脾摘出の䬭血に及ばす影響

上述の实験によつて惹起された蚠血の経過か， 䂆摘出によって影響されるか否が追究する目的 で蜰靜胍結热後 1 時間，4 日, 7 日，14 日及び 28 日に夫々脾摘出を行い，爾媵の坌血の経過を観察 した.

結禁值後及び4日後に脾摘出を行なつた例では 鿉前の $10 \%$ 20\%の赤血球減少率支示した貧血か;
3〜5 週を極期として招来されており，質的に見 て該貧血の状態は正色性，正血球性であり，粉浾血 球の減少走している．白血球は脾摘出後一過性:

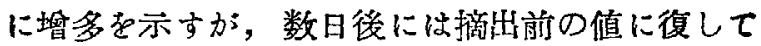
いる。栓球数に浽著変を見ない。

脾静脈結禁後 1 週, 2 週, 及び 4 週に摘脾を行 なつた例では結禁手術後 3〜 5週を極期とする盆 血老招来し，赤血球の減少率怡 40〜60\%である。

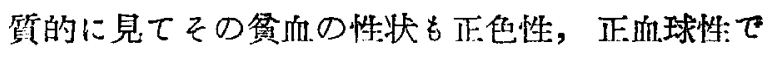
網赤血球数名減少し，回復期に於ける軽度の絧赤 血球增多の度は結禁単独例に比して大美加無い。 白血球数は脾摘出後一過性增多を示し，漸次旧值 


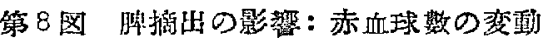

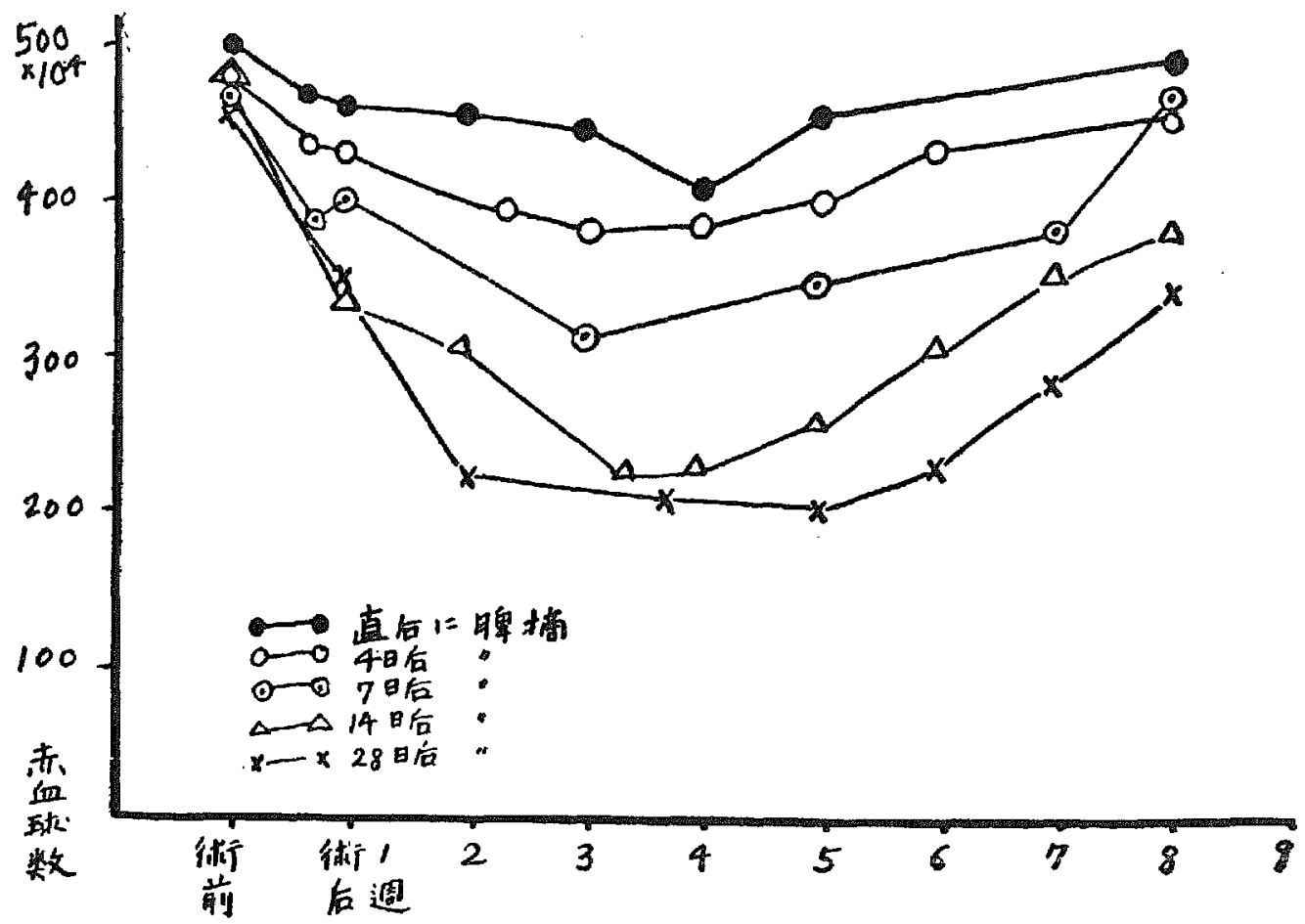

に低下している。柾球数には著変を認め得ない。 菜

動物に於ける脾赫脈結禁によつて惹起されて来

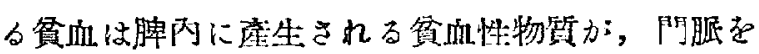
督由せすに（肝䑏の調節作用を受计すに）食道を

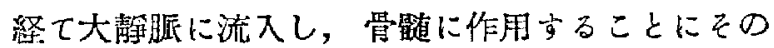
原因加求められてきた。加了る貧血性物質或は骨

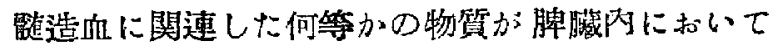

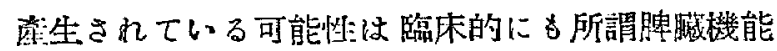

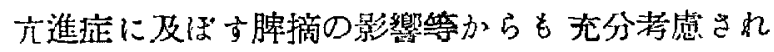
る事であり，位つて Bock 氏等の奏駼はこの可能 性:の一端を実証した点に意義がある様に罚的れ

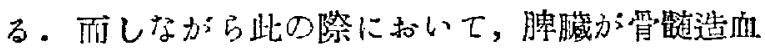
に如何なる機転で参阷しているかと云う点になる

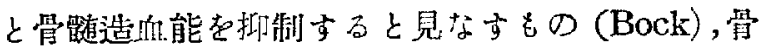
此道細胞の遊毕障害として取扱つているもの (Jombres)，或は脾藏网に於ける血球破壤の元堆

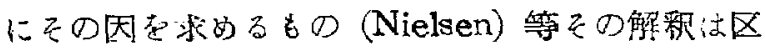
ヶでる。
上迅の藷者等の成績在綜合すると，筫血成因の

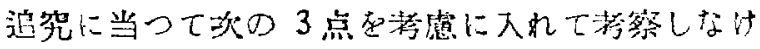
ればならぬと思法れる。

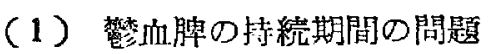

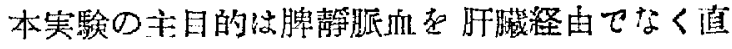
接大猙脈に導入することにあるが，手術後どのく

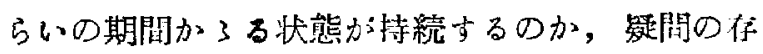
するところである．肉眼的或は組織学的に見て，

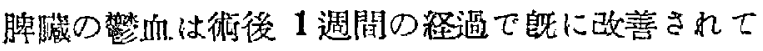
来るがこえれは副血行路の新生によつて脾队の椟 欰状態加軽くなつて来る事尼実証しているものと

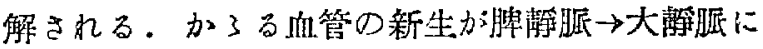
问つて盛んに黨まるているばかりでなく，臐藏い 門胍に向う新生も見逃し得ないことをエバンス素

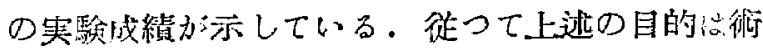

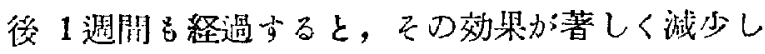
て行く事考考虑に入れなければならい。

(2) 骨髄穿刺液心変影

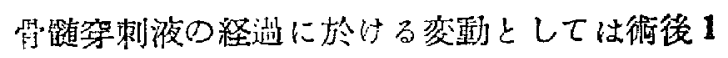


週新後に历る造血能の低下が注目される。組蟣標 本に就いて認められた骨㵦の桄血状態が，その像 の如くに起こつているものと市机ば，穿刺によつ て比較的末梢血在吸引儿易い条件にあり, 従つて 穿刺液所見の分析もこの点考虑すへきであるが， 闭球の低形成像仙了る因子の影響のみでは說 明し得るものでは無い様に思われる。本実験にお いて，これまで観察されて来た骨剈椺像の変化は主 として貧血の極期 $(3 \sim 5$ 週) 支中心とたもの で，赤芽球增多等を飞の所見として进へて居る か，（1）の考察加見て，骨傕に何等加の変化を 起こすとすれば，術後短期日の病変を追究する事 が必要てあって，貧血極期の封期に認められる骨 随の浾芽球增多は正常へ向つて回復しつろある一 速の変化像と解する事が出きる稼に思う。

犬の亦血球体內生存日数は人租球 $\varepsilon$ 略同様に 120 日前挠であると云われている (Hawkins). 從つて 短時日の闒に急激に進展して来る䞄血は大 量の出血か溶血存挎甞することか出来るか，本実 験において惹起される貧血怯術後から $3 \sim 5$ 週に につて漸次淮展して居る。この事は，初期に見ら れる骨璡造血能の低下と結び付けて溚えても，そ

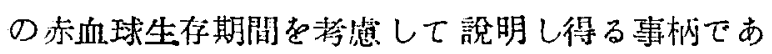
る。仮りに溶血办源因であるとす机ばか了る病的 な機転は筫血の極期に最も强力でなければならな いわけで，(1)の考察から見ても無理があり，血 清胆色素濃度の上昇しない事や著明な網赫血球增 多老認めない事等からも說明し難い様に思われ る.出血に就いては貧血極期の頃に出血性素因沖 訕明されす，亦大量の佔血を起こした状態は意起 されていない。

\section{（3）脾摘出の影響}

脾靜胍結奖後, 直後, 4 日, 1 週間, 2 週間, 4 週 間に摘脾した成績では，何れも結紮単独例と貧血 の起こり方及び貧血の性状等類似した貧血孛認め た。再後及び 4 日後の脾摘出例ではその貧血の度 命の上で結禁単独例に比して稍々軽度であり，(1) 及び (2)の浘察加推祭しても脾摘の貧血への好 影響を望む可能性が存在するが，単に脾臟を摘出
しただけでも 10〜 50\%の赤血球減少率在示す盆血 が作均 4 週後を中心として起こるという報告もあ

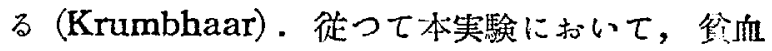
の值接的な原因を除く意味での脾摘の効果を牛远 する事は壃重を要し，影響の認め難い事を考察す べさでるかも知れないか例数の少ない点確言令 る事は出来ない，1週以後の摘脾例では，筫血の 発生に殆ど影響は算い様である。

以上者総括すると，本実験によつて惹起される 分血は骨璡の一過性の造血能低下を 主要因として 招来される事が考察されるが，飞の病的機転とし

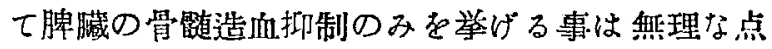
があり，等しく胑埛機能走仮定するとしても血液

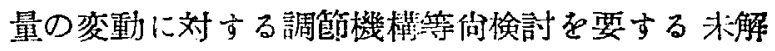
決の閣题が多く含まれている様に思われる。

\section{結 铻}

Bock-Frenzel の実験を追試し，下記の所見を 得た。

（1）洞後 4～5 週を極期とする貧血の惹起す

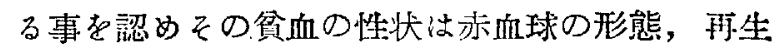
像の微弱性及び骨髄造血の低下等加ら一過性再生 不良性湓血の可能性:を考元しめる。

（2）本実験に於ける脾静脈血流を肝臓から遮 断する目的沙術值後には達せられるが，その期間 は短かく，10日後には相当量の脾靜胍血が肝淢を 経由して大靜脈へ流入する可能性が実証された。

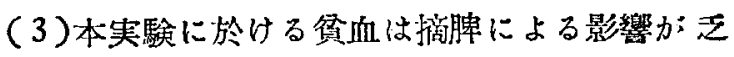

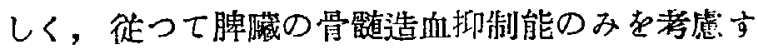
る事性㥀重を要すると思われる。

（4）本赛験において，白血球及び栓球の病変 は一定の傾向として把握し得なかつた。

本実験は「再生不良性貧血の治療」班の援助に よつた事を附記し謝意を表する。

\section{藝考文薪}

(1) Bock, H. E. und Frenzel, H. : Klin. Wschr. 1938 II, 1315.

(2) Jombres, P.: Zeitschr. f. d. ges; exp. Med. 106: 457, 1939.

(3) Nielsen, F. K.: Proceeding of the Third 
International congress of the International Society of Hematology; 102 108, 1950.

(4) Fekurs P. E. and Coulter, M.: Am. J. Med. Sci. 216; 643, 1948.

(5) Meyer, L. M., and Bloom, F.: Am. J. Med. Sci. 206; 637, 1943.

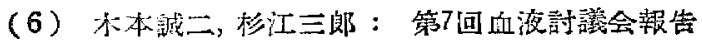
$87 \sim 98$ (1954).
(7) Krumbhaar, E. B. : Am. J. Med. Sci. $184 ; 215,1932$.

(8) Singer, K.: Am. J. Med. Sci. 210; 301.

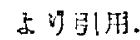

(9) Lauda, E.: Erg. inn. Med. 34, 1.

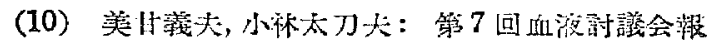
苫, 155 172, 1954.

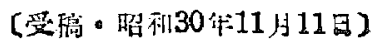

